\title{
Factors That Influence Rural Entrepreneurship: Case-Study Evidence from Torbat-E Heydarie, Kadkan District
}

\author{
Factores que influyen en el espíritu empresarial rural: evidencia de estudios \\ de caso de Torbat-E Heydarie, distrito de Kadkan
}

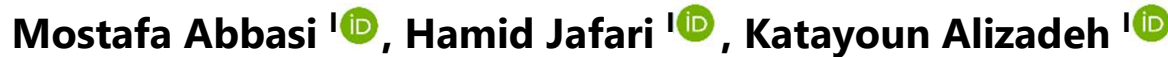

'Islamic Azad University, Mashhad, Iran

\begin{abstract}
Entrepreneurship is an important instrument in planning and realizing rural community development. Owing to current problems in societies, focusing on the rural entrepreneurship is of utmost importance. Entrepreneurship by creating new opportunities for employment and income plays an important role in improving socioeconomic conditions of villages. The aim of this study is to assess the factors influencing the development of rural entrepreneurship in a case study of villages in Torbat-e Heydarieh, Kadkan district. The research method was descriptive-analytic, and the data collection method was library and field studies. For data analysis, One-sample t-test with principal component analysis was used. The statistical population of the study was the villagers of Kadkan district of Torbat-e Heydarieh, from which 240 people were asked to complete a questionnaire. The validity of the questionnaire was evaluated using the Content and face validity with expert judgement. Reliability of the questionnaire was examined by Cronbach's alpha coefficient which for all studied domains was above 0.75 which indicated that questionnaire was satisfactory. The results indicated that economic factor was the most influential issue in the rural entrepreneurship. The results also showed that rural entrepreneurship provides a good context for creating jobs in agricultural and non-agricultural sectors and it is an important factor for achieving sustainable rural development.
\end{abstract}

Keywords: Entrepreneurship; Development; Village; Torbat Heydariyeh; Kodkan

\section{RESUMEN}

El espíritu empresarial es un instrumento importante en la planificación y realización del desarrollo de la comunidad rural. Debido a los problemas actuales de las sociedades, es de suma importancia centrarse en el espíritu empresarial rural. El espíritu empresarial mediante la creación de nuevas oportunidades de empleo e ingresos juega un papel importante en la mejora de las condiciones socioeconómicas de las aldeas. El objetivo de este estudio es evaluar los factores que influyen en el desarrollo del espíritu empresarial rural en un estudio 
de caso de pueblos de Torbat-e Heydarieh, distrito de Kadkan. El método de investigación fue descriptivoanalítico, y el método de recolección de datos fue biblioteca y estudios de campo. Para el análisis de datos, se utilizó la prueba t de una muestra con análisis de componentes principales. La población estadística del estudio fueron los habitantes del distrito de Kadkan de Torbat-e Heydarieh, de los cuales se pidió a 240 personas que completaran un cuestionario. La validez del cuestionario se evaluó mediante el contenido y la validez aparente con juicio de expertos. La confiabilidad del cuestionario se examinó mediante el coeficiente alfa de Cronbach, que para todos los dominios estudiados fue superior a 0,75 , lo que indicó que el cuestionario era satisfactorio. Los resultados indicaron que el factor económico fue el tema más influyente en el emprendimiento rural. Los resultados también mostraron que el espíritu empresarial rural proporciona un buen contexto para la creación de puestos de trabajo en los sectores agrícolas y no agrícolas y es un factor importante para lograr el desarrollo rural sostenible.

Palabras clave: Emprendimiento, Desarrollo; Pueblo; Torbat Heydariyeh; Kodkan

\section{INTRODUCTION AND STATEMENT OF THE PROBLEM}

The village is the oldest form of human settlements and human life. Villages as first communities have played a significant role in prosperity of societies and civilizations. Regarding the fact that they were responsible for national development process, especially for food supply, their growth and development is of great importance and necessity (Hosseini, 2011: 63). Financial issues, especially finding a job, has been an important reason for villagers' migration to the cities. It causes many problems such as marginalization, low quality of life, and lack of jobs and higher rates of crime in cities. On the other hand, the decline in the growth of the agricultural sector in rural areas and the reduction of employment by $23.4 \%$, reveal that in the future, agricultural development cannot guarantee economic growth and eradication of poverty in the countryside, therefore, it is necessary to focus on other sectors. (Najafi Kani et al., 2015: 37)

\subsection{Rural Entrepreneurship}

More than a century, researchers, sociologists, economists, geographers, government agencies, and concerned individuals have sought to define "rural" more precisely according to social, economic, and environmental factors. There is a cultural hierarchy that considers urbanity as positive trait and rurality a negative one. This hierarchy is not in many way culturally valid, as it is fairly easy to turn upside down in the form "urban - bad, rural - good". (Ritzer, 2007: 24) 
Rurality is a controversial concept, for example, Dobson (2005) defines rural areas in the United States with differences in economics, values, environment, and climate. What can be deduced from his definition is that economics represent agricultural occupation and values refer to issues such as religion and traditions of self-sufficiency, the environment which includes unique and beautiful landscapes, animals and livestock, and trees and farms. Finally, it also implies that atmosphere is a relaxed lifestyle that is a safe and wholesome place to raise kids. Another seminal work about rurality is Cloke's (2006) enquiry; he recognizes three significant theoretical frameworks which have been influential in constructing the conceptualization of rurality. The first can be thought as functional concepts of rurality. In this framework, a village can be defined in terms of areas which are used for agriculture and forestry, land use, including smaller settlements and residents, and it create a way of life which are characterized by respecting the environment and the great landscapes. A recent national program in Iran aimed at lending 4\% interest rate loan to so-called rural entrepreneurs is a clear example of the functional meaning of rurality, and the concept of supply side of entrepreneurship (Thornton, 2011: 35).

Our study area is located in Kadkan section, one of the rural sections of Torbat-e Heydarieh city in Khorasan Razavi province. Its population is 12805 ( 6,438 men and 6,367 women) with 3932 households and two rural districts of kadkan and rafijeh with population of 5,941 and 3,145 which have 17 and 16 inhibited villages (Statistical Center of Iran 2018).

In this study, we seek to answer the following questions:

1. What factor influence the development of rural entrepreneurship in the studied area?

2. What factors have the greatest impact on entrepreneurship in the studied villages?

1.2 The necessity of entrepreneurship and its role in rural areas

Entrepreneurship is very influential factor in rural development; because it can improve the socio-economic conditions of the villages by creating new employment and income opportunities. Therefore, measuring the entrepreneurship of the villagers and trying to develop and strengthen it in the process of rural development by providing its initial grounds is of particular importance. Due to special ecological and socio-economic 
conditions, rural areas face many problems, such as poverty and deprivation (Rezvani and Najarzadeh, 2008: 161). According to Reagan (2002: 23), rural entrepreneurship generates wealth, employment, greater income and improved life quality and helps local people to engage in the economy. (Heritot, 2002: 19) by considering entrepreneurship as a pattern for economic growth, defined rural development as the process of encouraging, assisting and offering managerial and technical help to rural entrepreneurs, transportation and rural communication and information services, natural resource management. Therefore, the development of rural entrepreneurship has the potential to diversify and increase agricultural and non-agricultural production of rural people and, consequently, increase income and provide good opportunities to reduce livelihood risk and increase sustainable food security in rural areas and can be one of the suitable grounds for creating employment opportunities in agricultural and non-agricultural sectors. (Dabson \& other, 2003: 11)

\section{DEFINITION}

Entrepreneurship has been present in all different aspects of human life since the beginning of human creation and has been the basis for all human developments and progress and there are various definitions of it (Samad Aghaei, 2014: 57).

\subsection{Review of literature}

Although entrepreneurial activities have traditionally and experimentally existed in different societies from the beginning; however, researcher in recent decade have studied it based on scientific frameworks and methodological models (Bouzarjomehri et al., 2014: 452)

Table1 - The following table lists some research that has been done in this área

(Continue...) 


\begin{tabular}{llll}
\hline Researcher & Year & Title & Results
\end{tabular}

\begin{tabular}{|c|c|c|c|}
\hline & & Analysis of different & 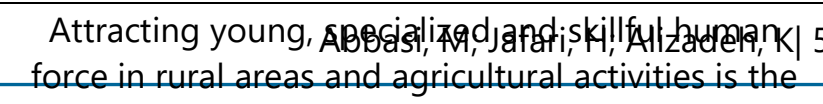 \\
\hline Rezvani et al & 1999 & $\begin{array}{l}\text { aspects of the rural } \\
\text { entrepreneurship in } \\
\text { development of rural areas }\end{array}$ & $\begin{array}{l}\text { main solution for improving entrepreneurship in line } \\
\text { with sustained development }\end{array}$ \\
\hline $\begin{array}{l}\text { Rokn-aldin } \\
\text { eftekhari et al }\end{array}$ & 2010 & $\begin{array}{c}\text { Agricultural } \\
\text { Entrepreneurship } \\
\text { Development Strategies in } \\
\text { Rural Areas: A Case Study } \\
\text { of Khodabandeh County } \\
\text { Villages }\end{array}$ & $\begin{array}{l}\text { High Capabilities and potentials of the region, the } \\
\text { threshold of innovation and creativity in the } \\
\text { agricultural sector of rural areas need to be } \\
\text { reviewed and appropriate policies offered for } \\
\text { solving problems }\end{array}$ \\
\hline $\begin{array}{c}\text { Faraji } \\
\text { sabokbar et } \\
\text { al }\end{array}$ & 2011 & $\begin{array}{c}\text { Prioritization of } \\
\text { Entrepreneurship } \\
\text { Development in Rural } \\
\text { Areas Using Prometric } \\
\text { Technique : Case Study of } \\
\text { Suburban Rural District of } \\
\text { Khodabandeh County, } \\
\text { Zanjan Province }\end{array}$ & $\begin{array}{l}\text { The Rural entrepreneurship is a new approach in } \\
\text { development theories for empowerment and } \\
\text { capacity building in rural areas with the aim of } \\
\text { reducing the gap between urban and rural areas, } \\
\text { creating economic, social, environmental and } \\
\text { institutional equality. }\end{array}$ \\
\hline Alidost et al & 2012 & $\begin{array}{l}\text { Prioritization of obstacles } \\
\text { of rural women } \\
\text { entrepreneurship } \\
\text { development in Garmsar }\end{array}$ & $\begin{array}{c}\text { Economic and educational obstacles are the most } \\
\text { important ones in the development of } \\
\text { entrepreneurship of this segment of society, } \\
\text { respectively }\end{array}$ \\
\hline
\end{tabular}

\begin{tabular}{|c|c|c|c|}
\hline behmand & 2015 & $\begin{array}{l}\text { the Role of Rural Tourism } \\
\text { in the Development of } \\
\text { Rural Entrepreneurship of } \\
\text { women }\end{array}$ & $\begin{array}{l}\text { In the recent past, rural women have worked } \\
\text { alongside men. However, due to social, economic } \\
\text { and cultural developments, the role of women in } \\
\text { rural activities has been greatly reduced in recent } \\
\text { years. This has caused many social and economic } \\
\text { problems to the villages. }\end{array}$ \\
\hline Anbarlo et al & 2016 & $\begin{array}{l}\text { the role of women } \\
\text { entrepreneurship in the } \\
\text { economic development of } \\
\text { human settlements }\end{array}$ & $\begin{array}{c}\text { Focusing on women entrepreneurship and } \\
\text { empowering women and their decisive role in } \\
\text { sustainable development should be considered in } \\
\text { theory and application. }\end{array}$ \\
\hline $\begin{array}{l}\text { Eltiyami niya } \\
\text { et al }\end{array}$ & 2016 & $\begin{array}{c}\text { the role of } \\
\text { entrepreneurship process } \\
\text { in sustainable rural } \\
\text { development with } \\
\text { emphasis on social } \\
\text { development }\end{array}$ & $\begin{array}{l}\text { One of the dynamic tools in the development } \\
\text { process is the entrepreneurship that can provide the } \\
\text { conditions for the development process in its } \\
\text { various dimensions, especially in the social } \\
\text { dimension. Social development is one of the } \\
\text { important factors in achieving sustainable rural } \\
\text { development, which improves the quality of life of } \\
\text { villagers, social justice, collective participation and } \\
\text { rural trust and security. }\end{array}$ \\
\hline Khateri et al & 2016 & $\begin{array}{l}\text { the role of rural handicrafts } \\
\text { and tourism in developing }\end{array}$ & $\begin{array}{l}\text { Given that about half of the country's population } \\
\text { and a significant portion of the economically active }\end{array}$ \\
\hline
\end{tabular}


rural women's

entrepreneurship population are women and their proportion in the educated community is still increasing, but They have not gained merit in the national economy. However, women entrepreneurs in their path have been able to achieve successes that can have a tremendous impact on the economic, social and political arenas of the country.

\begin{tabular}{|c|c|c|}
\hline \multirow{6}{*}{$\begin{array}{l}\text { Ramezan } \\
\text { zade } \\
\text { lesboyiee et } \\
\text { al }\end{array}$} & \multirow{6}{*}{2016} & Analysis of the \\
\hline & & Relationship between \\
\hline & & $\begin{array}{l}\text { Awareness and } \\
\text { Entrepreneurship of Local }\end{array}$ \\
\hline & & Communities in the \\
\hline & & Tourism Sector (Case \\
\hline & & $\begin{array}{c}\text { Study: Rural Areas of } \\
\text { Mianband, Noor) }\end{array}$ \\
\hline
\end{tabular}

Entrepreneurship is growing rapidly in important economic sectors and one of these areas is tourism. In order to develop entrepreneurial activities in the rural tourism sector, various factors such as environmental capacities with emphasis on the tourism sector, personal, psychological factors, etc. are influential.

Nevertheless, the rural areas of the country have good capabilities and potentials to help the development of the country. In this regard, more attention to rural entrepreneurship is a necessity. On Rewayiee $2016 \quad \begin{gathered}\text { Challenges of rural } \\ \text { entrepreneurship }\end{gathered}$ the other hand, we know that entrepreneurship is a key factor to the survival of organizations and is a source of employment and growth and development.

\begin{tabular}{|c|c|c|c|}
\hline $\begin{array}{l}\text { Raphael bar } \\
\text { et al }\end{array}$ & 1998 & $\begin{array}{l}\text { Entrepreneurship and rural } \\
\text { industrialization: } \\
\text { Comparing urban and rural } \\
\text { patterns of locational } \\
\text { choice in Israel }\end{array}$ & $\begin{array}{l}\text { Paying attention to local characteristics can be } \\
\text { achieved by attracting local and indigenous people } \\
\text { and using this power to create relative industrial } \\
\text { development in rural areas. }\end{array}$ \\
\hline Louvre et al. & 2012 & $\begin{array}{l}\text { Study of modern } \\
\text { entrepreneurship and } \\
\text { agriculture in rural areas } \\
\text { Case of the Netherlands }\end{array}$ & $\begin{array}{l}\text { Age has an effect on agricultural employment in the } \\
\text { region and the activation of knowledge } \\
\text { infrastructures, management, systems and chains } \\
\text { are the requirements of rural entrepreneurship. }\end{array}$ \\
\hline Zaltin et al & 2013 & $\begin{array}{l}\text { Rural Entrepreneurship A } \\
\text { Case Study of the United } \\
\text { States }\end{array}$ & $\begin{array}{c}\text { Access to resources, need for information, skilled } \\
\text { labor, technology and capital are among the } \\
\text { problems of villages in the direction of } \\
\text { entrepreneurship. }\end{array}$ \\
\hline kasabov & 2014 & $\begin{array}{l}\text { When an initiative } \\
\text { promises more than it } \\
\text { delivers: a multi-actor } \\
\text { perspective of rural } \\
\text { entrepreneurship } \\
\text { difficulties and failure in } \\
\quad \text { Thailand }\end{array}$ & $\begin{array}{l}\text { National governments invest in initiatives aimed at } \\
\text { encouraging rural entrepreneurship on the } \\
\text { assumption that it contributes to competitiveness } \\
\text { and employment inadequacies of one-size-fits-all } \\
\text { policies seeking to encourage rural entrepreneurship } \\
\text { by failing to address the needs and capabilities of } \\
\text { the involved entrepreneurs. }\end{array}$ \\
\hline
\end{tabular}




\begin{tabular}{|c|c|c|}
\hline \multirow{3}{*}{ kasabov } & \multirow{3}{*}{2015} & When Rural \\
\hline & & $\begin{array}{c}\text { Entrepreneurship } \\
\text { Marketing Does Not Work }\end{array}$ \\
\hline & & $\begin{array}{c}\text { A Case of OTOP Failure in } \\
\text { Thailand }\end{array}$ \\
\hline
\end{tabular}

When Rural

Entrepreneurship

Thailand
The input of firm resources to competitive advantage has generally been theorised and empirically examined in the context of large companies. Less frequent are discussions about resources in small firms and entrepreneurial ventures. These issues deserve empirical testing, though, since entrepreneurship plays a substantial role in economic development and contributes to rural communities

\section{Madann et al 2015 Rapid growth rates in India \\ and other Asian countries}

Entrepreneurship has significantly reduced the incidence of poverty, as well as increased inequality in local sub-areas, especially in rural and urban areas, and between skilled and inefficient workers.

\begin{tabular}{|c|c|c|}
\hline Kaushik et al. & 2016 & $\begin{array}{l}\text { How higher education in } \\
\text { rural India helps human } \\
\text { rights and } \\
\text { entrepreneurship }\end{array}$ \\
\hline dobson & 2016 & $\begin{array}{l}\text { Supporting rural } \\
\text { entrepreneurship }\end{array}$ \\
\hline Asitik & 2016 & $\begin{array}{l}\text { Establishing The Link } \\
\text { Between Entrepreneurship, } \\
\text { Built Capital And Poverty } \\
\text { Reduction In Rural } \\
\text { Northern Ghana }\end{array}$ \\
\hline
\end{tabular}

This endeavor has certainly improved the lives and prospects of many women.

Instead of trying to get an overview of any general program that may directly or indirectly affect entrepreneurship that focuses on the main topic.

This strategy overlooks the fact that the conditions for entrepreneurship in rural environments are underpinned significantly by other factors, not least those related to built capital or infrastructure. This paper argues that built capital can either facilitate or restrict rural entrepreneurship and consequently poverty reduction.

Religious, socioeconomic and structural forces play

Barriers to the development and progress muhmmad 2016 of entrepreneurship in rural Pakistan a significant role in suppressing social and cultural capital in rural areas of Pakistan, explaining the low level of entrepreneurship in these areas. Social and cultural capital requires a certain socioeconomic context for entrepreneurship to thrive. 
Jeanette et al 2017
Social entrepreneurship among Kenyan farmers: A case example of acculturation challenges and program successes
Success of the programs may be attributed, in part, to individual and group cultural learning and the appropriateness of the servant leader approach to the Kenyan context.
While highlighting the factors that enhance success as well as those that impede development, the study found that the learnership contributed significantly to social transformation through rural entrepreneurship.
Rural entrepreneurship Koyana 2016 and transformation: the role of learnships
The lack of financial capital, lack of appropriate technologies, lack of the market, lack of raw materials, lack of skills and lack of commitments restrains ability of rural MSEs to create value. Legal concerns, suppliers, customers, competitors, middlemen and transport concerns limits the abilities of rural MSEs to create value.
Rural entrepreneurship in Tanzania: why are micro msamula 2017 and small enterprises not creating value in furniture manufacturing industry?
Social capital and female entrepreneurship in rural

Jejips et al
2018 regions: Evidence from Vietnam
Social capital increases women's willingness to move from family entrepreneurship to organizational entrepreneurs and access and availability and distance to market is influential too.

Source: Authors (2020)

\section{RESEARCH METHODS}

Research purpose is applied and its method is descriptive-analytic. For data collection, Field and non-field methods were used, while in order to complete the questionnaires, the survey method was used and the questionnaires were distributed and collected within a month. 240 people were selected as a sample. According to the research questions and the characteristics of the people, a 15 items questionnaire was developed and completed by sample. The questionnaire's validity was examined via content and face validity with the 
judgment of experts (university professor and statistician). Its reliability was examined using Cronbach's alpha coefficient, which indicates the desirable agreement of the questionnaire.

Table 2 - Cronbach alpha of variables

\begin{tabular}{|c|c|c|c|c|c|c|c|c|}
\hline Index & Number & Mean & $\begin{array}{l}\text { Standard } \\
\text { variation }\end{array}$ & Variance & Skewness & Kurtosis & Minimum & Maximum \\
\hline Consultation & 50 & 3.68 & 0.74 & 0.77 & -0.64 & 0.54 & 1.33 & 5.00 \\
\hline teaching & 50 & 3.78 & 0.71 & 0.82 & -0.81 & 0.16 & 1.50 & 5.00 \\
\hline $\begin{array}{l}\text { Personal } \\
\text { experience }\end{array}$ & 50 & 3.44 & 0.78 & 0.70 & -0.55 & -0.04 & 1.20 & 5.00 \\
\hline Marketing & 50 & 3.40 & 0.88 & 0.91 & -0.85 & 0.72 & 1.00 & 5.00 \\
\hline Development & 50 & 3.39 & 0.72 & 0.80 & -0.84 & 1.68 & 1.00 & 5.00 \\
\hline Capital & 50 & 3.71 & 0.78 & 0.64 & -0.60 & 1.02 & 1.00 & 5.00 \\
\hline $\begin{array}{l}\text { Marketing, } \\
\text { development } \\
\text { and capital }\end{array}$ & 50 & 3.501 & 0.57 & 0.72 & -1.22 & 3.23 & 1.00 & 4.83 \\
\hline
\end{tabular}

Source: Authors (2020)

According to Table 2, Cronbach's alpha value which is higher than $70 \%$, shows that the research instrument has high internal consistency and good reliability. The collected data were analyzed using SPSS software and one-sample T method. Cronbach's alpha coefficient which is between 0 and 1 were used to examine the internal consistency of measurement tools. 1 shows the highest correlation and 0 indicates the lowest correlation. As the percentage is closer to 100 , the validity of questionnaire is higher. The alpha coefficient of less than $60 \%$ is usually considered unacceptable, a range of $70 \%$ is acceptable and above $80 \%$ is considered good. The overall Cronbach's alpha value in the questionnaire was 0.758 , which is acceptable considering the above, and indicates the good reliability of the research questionnaire. Based on the sample of 50, the Cronbach's alpha level of the questionnaire for its dimensions is listed below. According to the obtained values, the reliability of the questionnaire is desirable. 
Table 3 - Dimensions of research's variables

\begin{tabular}{|c|c|c|}
\hline \multicolumn{2}{|c|}{ Elements } & \multirow{2}{*}{$\begin{array}{c}\text { Indexes } \\
\text { Consulting, perseverance and resistance to } \\
\text { problems, familiarity with business rules, business } \\
\text { experience, rural capital status, self-confidence, } \\
\text { participatory spirit, responsibility, literacy }\end{array}$} \\
\hline Potential and & $\begin{array}{c}\text { Personal } \\
\text { characteristics }\end{array}$ & \\
\hline $\begin{array}{l}\text { development of } \\
\text { entrepreneurship } \\
\text { and rural } \\
\text { employment }\end{array}$ & $\begin{array}{l}\text { Marketing, } \\
\text { development } \\
\text { and capital }\end{array}$ & $\begin{array}{l}\text { Allocating subsidies to entrepreneurial activities, } \\
\text { compiling a document on national } \\
\text { entrepreneurship development, encouraging local } \\
\text { investors, the existence of property and credit } \\
\text { institutions, helping the villagers to allocate capital } \\
\text { by the government, buying the products of the } \\
\text { villagers, developing the wealth of the villagers }\end{array}$ \\
\hline
\end{tabular}

Source: Authors (2020)

\section{GENERAL CHARACTERISTICS OF RESPONDENTS}

The distribution of respondents according to age groups in the present study was as follows: $26.6 \%$ in the age group 20 - 29 and 40\% in the age group 30-39, 20\% 40-49 and 13.4\% 50 years and above, their literacy status shows. $75.41 \%$ of them were literate and $24.59 \%$ of them were illiterate. Their employment status shows that $41.25 \%$ of them were unemployed and $58.57 \%$ of them were employed. Their entrepreneurial background shows that $23.75 \%$ of the respondents did not have an entrepreneurial background and 76.25 people have an entrepreneurial background.

\section{QUESTIONNAIRE INDICATORS}

\subsection{Personal characteristics}

Table (3) has 2 measures that according to the respondents, the weighted average of "education" is 3.78 so it is placed in the first rank, "consultation" with a weighted average of 3.68 is in second rank and "personal experience" with a weighted average of 3.44 is in the third rank. In describing the individual features, it can be said that personal characteristics 
are the main resource of entrepreneurs; as people are always looking to take advantage of opportunities to create something new or change it and turn threats into opportunities and use them for the benefit of themselves and society. Entrepreneurs see failure as a good opportunity to achieve success and insights that can paved their way for realizing all their dreams.

Table 4 - Variance and standard deviation of personal characteristics

\begin{tabular}{cccccccccc}
\hline Index & Number & Mean & $\begin{array}{c}\text { Standard } \\
\text { variation }\end{array}$ & Variance & Skewness & Kurtosis & Minimum & Maximum & rank \\
\hline Consultation & 50 & 3.68 & 0.74 & 0.77 & -0.64 & 0.54 & 1.33 & 5.00 & 2 \\
\hline teaching & 50 & 3.78 & 0.71 & 0.82 & -0.81 & 0.16 & 1.50 & 5.00 & 1 \\
\hline $\begin{array}{c}\text { Personal } \\
\text { experience }\end{array}$ & 50 & 3.44 & 0.78 & 0.70 & -0.55 & -0.04 & 1.20 & 5.00 & 3 \\
\hline $\begin{array}{c}\text { Personal } \\
\text { characteristic }\end{array}$ & 50 & 3.63 & 0.64 & 0.63 & -0.89 & 0.90 & 1.46 & 4.88 & $*$ \\
\hline
\end{tabular}

Source: Authors (2020)

\section{MARKETING, DEVELOPMENT AND CAPITAL}

In table (3), which is about marketing, development and capital, based on the mentioned indicators and ranking, the weighted average of "capital" is 3.71 which is considered as the first rank, the weighted average of "marketing", is 3.40, placed in second rank, the weighted average of the last rank "development" is 3.39, therefore it can be concluded that the respondents consider "capital" as the most important one because basically no work or development is possible without it.

(Continue...) 
Table (5) variance and standard deviation of marketing, development and capital

\begin{tabular}{ccccccccccc}
\hline Index & $\begin{array}{c}\text { Numb } \\
\text { er }\end{array}$ & $\begin{array}{c}\text { Mea } \\
\mathbf{n}\end{array}$ & $\begin{array}{c}\text { Standa } \\
\text { rd } \\
\text { variati } \\
\text { on }\end{array}$ & $\begin{array}{c}\text { Varian } \\
\text { ce }\end{array}$ & $\begin{array}{c}\text { Skewn } \\
\text { ess }\end{array}$ & $\begin{array}{c}\text { kurto } \\
\text { sis }\end{array}$ & $\begin{array}{c}\text { minim } \\
\text { um }\end{array}$ & $\begin{array}{c}\text { Maxim } \\
\text { um }\end{array}$ & $\begin{array}{c}\text { ran } \\
\mathbf{k}\end{array}$ \\
$\begin{array}{c}\text { Marketing } \\
\text { Developm } \\
\text { ent }\end{array}$ & 50 & 3.40 & 0.88 & 0.91 & -0.85 & 0.72 & 1.00 & 5.00 & 2 \\
$\begin{array}{c}\text { Capital } \\
\begin{array}{c}\text { Marketing } \\
\quad\end{array}\end{array}$ & 50 & 3.39 & 0.72 & 0.80 & -0.84 & 1.68 & 1.00 & 5.00 & 3 \\
$\begin{array}{c}\text { developm } \\
\text { ent and } \\
\text { capital }\end{array}$ & 50 & 3.50 & 0.78 & 0.64 & -0.60 & 1.02 & 1.00 & 5.00 & 1 \\
\hline
\end{tabular}

Source: Authors (2021)

\section{TESTING HYPOTHESES}

There is a significant association between personal characteristics of villagers and entrepreneurship development.

Statistical hypothesis can be tested as the following:

$\mathrm{HO}$ : There is no significant association between personal characteristics of villagers and entrepreneurship development. (The mean of the variable is not more than 3).

$\mathrm{H} 1$ : There is a significant association between personal characteristics of villagers and entrepreneurship development. (The mean of the variable is more than 3).

The results of t-test are presented below:

(Continue...) 
Table (6): the result of t-test comparing the mean of impact of personal characteristics and entrepreneurship development with score 3

\begin{tabular}{ccccccc}
\hline Hypothesis & Mean & $\begin{array}{c}\text { Standard } \\
\text { deviation }\end{array}$ & $\begin{array}{c}\mathbf{T} \\
\text { statistics }\end{array}$ & $\begin{array}{c}\text { Freedom } \\
\text { degree }\end{array}$ & $\begin{array}{c}\mathbf{P} \\
\text { value }\end{array}$ & $\begin{array}{c}\text { Hypothesis } \\
\text { result }\end{array}$ \\
\hline $\begin{array}{c}\text { Mean of impact of } \\
\text { personal } \\
\text { characteristic and } \\
\text { entrepreneurship } \\
\text { development }\end{array}$ & 3.635 & 0.643 & 11.428 & 133 & 0.000 & confirm \\
\hline
\end{tabular}

Source: Authors (2020)

It is observed that the p-value divided by 2 tests is less than 0.05 and the t-statistic is positive (11.428), so the null hypothesis that impact of personal characteristics of villagers and entrepreneurship development is not significant is rejected, in other words, the mean of impact of personal characteristics of villagers and entrepreneurial development is higher than average, so it can be concluded that personal characteristics are effective in the development of rural entrepreneurship, i.e. the first hypothesis is confirmed.

There is a significant relationship between marketing and entrepreneurship development.

$\mathrm{HO}$ : There is no significant relationship between marketing and entrepreneurship development. (The mean of variable is not more than 3 ).

$\mathrm{H} 1$ : There is a significant relationship between marketing and entrepreneurship development. (the mean of variable is more than 3).

The results of $t$-test are presented below:

(Continue...) 
Table (7): the results of $\mathrm{t}$ - test comparing the significant relationship between marketing and development of rural entrepreneurship with score 3

\begin{tabular}{|c|c|c|c|c|c|c|}
\hline test & Mean & $\begin{array}{l}\text { Standard } \\
\text { deviation }\end{array}$ & $\begin{array}{c}\mathbf{T} \\
\text { statistics }\end{array}$ & $\begin{array}{c}\text { Degree } \\
\text { of } \\
\text { freedom }\end{array}$ & $\begin{array}{c}p- \\
\text { value }\end{array}$ & result \\
\hline $\begin{array}{c}\text { the relationship } \\
\text { between marketing } \\
\text { and rural } \\
\text { entrepreneurship } \\
\text { development }\end{array}$ & 3.501 & 0.574 & 10.087 & 133 & 0.000 & confirmed \\
\hline
\end{tabular}

Source: Authors (2021)

It is observed that the p-value divided by 2 tests is less than 0.05 and the t-statistic is positive (10.087), so it can be said that the null hypothesis implying that there is a significant relationship between marketing and rural entrepreneurship development is not significant, so it is rejected, in other words, the impact of a significant relationship between marketing and rural entrepreneurship development is more than average, so there is a significant relationship between marketing and entrepreneurship development, i.e. the second hypothesis is confirmed.

\section{SUMMARIES, CONCLUSIONS AND SUGGESTIONS}

The following strategies are influential in the development of entrepreneurship in rural areas:

- considering private sector investment in rural areas;

- Encouraging participation of local communities in rural development programs;

- Teaching different skills to talented villagers;

- Focusing and emphasizing on the indigenous knowledge of the villagers and the development of rural industries by entrepreneurs with the aim of 
facilitating employment in the villages and, consequently, preventing the migration of villagers to the cities;

- Building good and wide connecting roads for driving trucks and constructing good accommodation and suitable service complexes in the area, which are already seen in some places. Raising security should be taken seriously by establishing police station and sometimes checkpoint in the area. The most important thing is to build a suitable educational environment for the villagers so they do not forced to travel to neighboring villages to study which ultimately may encourage them to migrate.

- Consulting with locals is very affective because in doing so, not only respecting the people but also encouraging them to compete for more cooperation in the development project, etc., moreover, the residing people are more aware of the problems in each area therefore it will save the money and appropriate facilities will be built and used in a suitable place for the residents;

- by creating good employment opportunities with good income prevent rural people's migration to urban areas and village's destruction which can mostly done through public and private investment in the area or paying long term, low interest rate loan so rural people work peacefully and not concerned about heavy repayments regarding the fact that farmers face many challenges including climate change, pest and others which may ruin their crop so they can't make the same profit every year.

The results reveal that entrepreneurship has a positive impact on economic, social, institutional and cultural aspects, which lead to improvement of national culture and identity, diversification of agricultural, industrial and rural services and activities, maintenance of the population with minimal damage to the rural environment, reduction of migration to cities and also providing employment, welfare and development in the village. Considering the above, it may be possible to prevent the destruction of rural areas and agriculture and reduce rural migration that put further pressure on the cities as their population are constantly increasing. 


\section{REFERENCES}

Audretsch, D. (2002). Entrepreneurship: a survey of the literature. London: Institute for Development Strategies.

Bouzarjomehri, Khadijeh, Romiani, Ahmad, Ismaili, Asia, (2014). Factors Affecting Entrepreneurship Growth in Strengthening Rural Communities for Sustainable Development, National Conference on Sustainable Rural Development in the Sixth National Development Plan, Scientific Association of Geography and Rural Planning, University of Tehran.

Cloke, P. (2006). Conceptualizing rurality. In P. Cloke, T. Mardsen, \& P. H. Mooney Eds., Handbook of rural studies. London: Sage.

Dabson, B. (2005). Entrepreneurship as a real community and economic development strategy. Rural policy research institute $\&$ truman school of public affairs. Columbia: University of Missouri.

Dabson, B. Malkin, J. Matthews, A. Pate, K. Stickle, S. (2003), Mapping Rural Entrepreneurship.

Farahani, Hossein, Zakieh Rasoulinia and Zahra Sedghi Saraskanroud, (2014) Factors Affecting Entrepreneurship Growth in Rural Areas Study: Jaber Ansar Village in Abdanan County, Space Economics and Rural Development, Volume 3, Number 9.

Governor of Torbat Heydariyeh city of Khorasan Razavi (2018)

Heritot, K. 2002, A new Approach to Rural Entrepreneurship a Case Study of Two Rural

Hosseini, Ismail, (2011), The role of entrepreneurship in the development of rural areas of Kaki section of Dashti province, Master's Degree in Geography and Rural Planning, Sistan and Baluchestan University.

Jeanette S.Martina, Milbord Novievicb. (2010), Social entrepreneurship among Kenyan farmers.International Journal of Intercultural Relation,34.

Najafi Kani, Ali Akbar, Mehdi Hesam and Hadiseh Ashour, (2015), Assessing the status of entrepreneurial development in rural areas: South Astarabad district in Gorgan province, Quarterly Journal of Space Economics and Rural Development, Fourth Year, No. 1

Reagan, B. (2002), Area Highgrowth Entrepreneurs Building the Rural Economy?, Center for the Stud of Rural America, Kansas City, Mo: Federal Reserve bank of Kansas City.

Ritzer, G. (2007). Contemporary sociological theory and its classical roots. New York: McGraw-Hill University of Jyvaskyla.

Rokanuddin Eftekhari, Abdolreza, Mehdi Taherkhani and Hamdollah Sajasi Gheidari; (2009) Dimensions and Factors Affecting the Development of Agricultural Entrepreneurship in Rural Areas Case Study of Villages of Khodabandeh County, Rural and Development Quarterly, Volume 12, Number 3. 
Samad Aghaei, Jalil, (2014) Research and Development in Entrepreneurial Organizations, Technology Growth Quarterly, Volume 1, Number 1.

Shahraki, H., Movahedi, R., \& Yaghoubi Farani, A. (2016). From Arturo Escobar's development theory to Antony Giddens's structuration theory: A social constructionist analysis of rural entrepreneurship and multifunctional agriculture. International Journal of Agricultural Resources, Governance and Ecology, 12, 406-426.

Statistical Center of Iran, (2016), excerpt from the results of the General Population and Housing Census 2016

Thornton, P. (1999). The sociology of entrepreneurship. Annual Review of the Social Sciences of Religion, 25, 19-46.

Vosooghi, M., \& Eemani, A. (2010). Ayande-ye Tose-ye Roosta'i va Chalesh-ha-ye Paydari future of rural development and sustainability challenges. Rural Development Journal, 12, 23-45.

\section{AUTHORSHIP CONTRIBUITIONS}

\section{Mostafa Abbasi}

PhD Student

E-mail: m.abbasi@gmail.com |

\section{Hamid Jafari}

PhD Student

E-mail: hamid.jafari922@gmail.com

\section{Katayoun Alizadeh}

PhD Student

E-mail: k.alizadeh@gmail.com

\section{HOW TO QUOTE THIS ARTICLE}

ABBASI, M; JAFARI, H; ALIZADEH, K. Factors That Influence Rural Entrepreneurship: Case-Study Evidence from Torbat-E Heydarie, Kadkan District. Revista de gestão, educação e tecnologia ambiental. Santa Maria, v.25, e9, 2021. Available from: https://doi.org/10.5902/2236117063506. Accessed: Month Abbreviated. Day, year. 